\title{
The influence of mindfulness and Buddhist rituals on the spirituality of students at STAB Maitreyawira Pekanbaru
}

\author{
Dharmaji Chowmas $^{1 *}$, Adi W Gunawan ${ }^{2}$,Sutikyanto ${ }^{3}$ \\ ${ }^{1}$ Buddhist Education, Maitreyawira Buddhist College, Pekanbaru, Indonesia \\ 2,3Buddhist Education, Smaratungga Buddhist College, Boyolali, Indonesia
}

\section{ABSTRACT}

The background of this study was the importance of the role of spirituality for students as the young generation. Nowadays, students experience academic stress, reducing academic achievement, reducing motivation, and increasing the risk of dropping out of school. This study was conducted to obtain an overview of the influence of mindfulness and Buddhist religious rituals on students' spirituality. The sample for this study was 106 students at STAB Maitreyawira Pekanbaru, which consisted of 3 batches, namely 2020, 2019, and 2018 batches. The data collection instrument was a closed questionnaire. This study was done quantitatively and analyzed by Pearson correlation test and multiple regression analysis. The results of data analysis showed that the higher the awareness and the higher the Buddhist religious rituals, the higher the spirituality of students at STAB Maitreyawira Pekanbaru and vice versa. This study concluded that students' spirituality could be improved through increased mindfulness and Buddhist religious rituals, either individually (alone) or jointly (together).

\section{ARTICLE INFO}

\section{Keywords:}

Spirituality; mindfulness;

Buddhist rituals

\section{Article History:}

Received: Dec $19^{\text {th }}, 2021$

Revised: Dec 27th, 2021

Accepted: Dec 28 $8^{\text {th }}, 2021$

Published: Dec 30th 2021

How to Cite in APA Style:

Chowmas, D., Gunawan, A.W., \& Sutikyanto. (2021). The influence of mindfulness and Buddhist rituals on the spirituality of students at STAB Maitreyawira Pekanbaru. Smaratungga: Journal of Education and Buddhist Studies, 1(2), 37-49. doi: $10.53417 /$ sjebs.v1i2.60

\section{Introduction}

Nowadays, students experience academic stress, such as pressure to achieve high grades and worries about receiving bad grades (Pascoe et al., 2020). Previous research has shown that academic-related stress can reduce academic achievement, reduce motivation and increase the risk of dropping out of school. The long-term impact is the reduced possibility of sustainable employment to the detriment of the government (Gutierrez et al., 2019; Pascoe et al., 2020). Spirituality is one way to overcome this pressure. Spirituality enables students to maintain harmony with the outside world and struggle to answer or gain strength when facing physical illness, emotional stress, social isolation, and even the fear of facing the threat of death.

Spirituality in Buddhism can be achieved by understanding the four noble truths (cattāri ariyasaccāni) through the realization of the eightfold paths (ariya-

*Corresponding author: dharmajizhuo@gmail.com

Published by Center of Research and Publication of Smaratungga Buddhist Collage

This is an open access article under the CC BY-NC 4.0 (https://creativecommons.org/licenses/by-nc/4.0/) https://doi.org/10.53417/sjebs.v1i2.60 
atthangika-magga); and the other is the law of karma and rebirth (kamma and punabbahava) (Hidayat, 2019). By understanding the law of karma and rebirth, the individual will be able to accept things that happen in his life that all forms of life that are present in an individual's life are the result of the individual's karma (actions), and Karma is usually preceded by volition (cetanā). The Buddha declared that cetana is kamma (A.III.415). The doctrine of rebirth will make individuals understand that life is continuity.

According to the Buddha, a birth to occur must meet three conditions: 1) a pair of (prospective) fertile parents; 2) sexual intercourse; 3) the existence of gandhabha (M.II.265). The term 'gandhabha' means coming from another place, referring to a flow of mental energy consisting of specific tendencies, faculties, and qualities which leaves the dead body, 'the mind moves upwards' (S.V.370) and develops again on the (prospective) mother's ovum fertilized. Such knowledge will increase understanding of life, increase spirituality.

The law of interdependent origination (pațiccasamuppāda) is one of the teachings of the Buddha, very essential and deeply spiritual. The basis of interdependent origination is that life or the world is built on a set of relationships that arise and stop depending on several other factors that condition them. The law of interdependent origination is described in two models: dukkha's arising and dukkha's passing away (S.II.1). Based on this principle of mutual creation, relativity, and interdependence, all the continuation of life, and the cessation of life, can be explained in the formula of the twelvefold causation (nidāna).

No less important is the teaching on the three characteristics of existence (tilakkhana), which are the absolute attributes of everything in this universe. Everything that exists in the physical world (rüpa) and all phenomena of the psyche ( $n \bar{a} m a$ ) is characterized by three characteristics: impermanence, suffering, and nonself (or without essence). According to David J. Kalupahana (1993), in the world of Buddhist spirituality, to preclude the possibility of misinterpreting the content of the jhäna experience, meditators are advised to review the content of the jhäna experience based on these three signs of the condition, conditioned existence.

The word spirituality comes from the word spirit, which means breath (Muslimin, 2013). Breath is a translation of the Greek noun pneuma which means spirit, namely everything that is not physical, not worldly, and not materialistic ways (Azman \& Syamsuddin, 2012; Niekerk, 2018; Pasiak, 2009). Spirituality is an individual's struggle and experience to make sense of life through the relationship between the individual and himself (intrapersonal), the individual and others (interpersonal), and beyond himself (transpersonal) in overcoming various life problems (Meezenbroek, Garssen, Berg, \& Tuytel, 2012; Meezenbroek et al., 2012; Yusuf et al., 2017).

Among the activities that are assumed to affect student spirituality is mindfulness. In Buddhism, mindfulness is equivalent to the word "sati" in Pali (Tirto \& Kahija, 2015), and the two types of practice for developing mindfulness are samatha and vipassanā bhāvanā (Cernetic, 2018). Jon Kabat Zinn defines mindfulness as paying attention intentionally to the present moment without judgment (Kabat-Zinn, 2015). There are many meanings and definitions to the concept of mindfulness. Generally, mindfulness is described as a natural human capacity, which is concerned with observing, participating, and accepting every state 
of life is in a state of balance or compassion. These moments can be practiced through meditation and contemplation. It can also be fostered through paying full attention to daily activities, such as eating, gardening, walking, listening, and schoolbased activities such as classroom work (Albrecht et al., 2012). In line with this, it can be found in the Satipațthāna Sutta (M.I.57).

Likewise, in the Aṇguttara Nikāya, the expression of unification of mind is not limited to solemn concentration because the same expression occurs concerning walking and standing (A.II.14) or hearing the Dhamma (A.III.175). In line with this, Kabat-Zinn in Kharlas, D. (2018) defines mindfulness as a process of paying attention specifically: intentionally, at the moment, non-judgmental. Such an opinion accords with the Mahāsatipațțhāna Sutta as follows, “... while walking, knowing that he is walking, while standing, knowing that he is standing, while sitting, knowing that he is sitting, while lying down, knowing that he is lying down (D.II.292).

Alimuddin, (2018) explains that formal mindfulness develops aspects of attention, increased alertness, and acceptance through breathing, yoga, walking meditation, and sitting meditation eating consciously. Meanwhile, Informal Mindfulness is an effort to bring full awareness in every moment carried out in daily life activities such as washing dishes, etc. Hakisukta (2018) also argues that Mindfulness can be practiced formally and informally. Mindfulness can informally be practiced by being aware of everyday habits and behaviors. An example is when eating, one can focus on the texture, taste, aroma, and color of each different food eaten.

There are four modes of right mindfulness (samma-sati) in Satipațhāna Sutta, namely: (1) kayānupassanā satipatthāna; (2) vedanānupassanā satipatthāna (3) cittānupassanā satipatthāna; and (4) dhammānupassanā satipatthāna (M.I. 55-6).

Mindfulness practices have been used to treat students' anxiety and depression. It helps them build problem-solving skills and positive thinking in many schools. Therefore, it is assumed to increase student spirituality. The research of Mathad et al. (2019), Dami et al. (2018), and Liu et al. (2020) show that increasing mindfulness increases spirituality. The research of Fouriana, Listyawati, E. (2017) concludes there is a relationship between spiritual well-being and mindfulness. Research (Tirto \& Kahija, 2015) reveals that mindfulness increases religious understanding, increasing spirituality.

Another activity is performing religious rituals. A Buddhist religious ritual is an activity carried out by Buddhists in expressing their belief in Buddhist teachings. One of the Buddhist religious rituals that we know in society and are celebrated by Buddhists in Indonesia is the pūjā rituals. For the Mahāyānas, pūjō is essentially a manifestation of skillful means (upāya), the disciplinary action that aids the spiritual determination of all beings, self, and others (Lewis, 2015). Pūjā is a means of strengthening and pouring faith and reminding us of the Tiratana (Buddha, Dhamma, and Sangha) (Ananda et al., 2014). There are two types of pūjā, namely āmisa pūjā and pațipatti pūjā (A.I.91).

At the Maitreya monastery, the filial piety ritual of $p \bar{u} j \bar{a}$ is prominent. One day there are three devotional sessions of $p \bar{u} j \bar{a}$. This activity follows the example of Maitreya Buddha as in the Bodhisattva Maitreya's Sutra on the Fundamental Vows of Buddhahood, “...Bodhisattva Maitreya three times during the day and three times 
throughout the night...respectfully behaves añjali...facing the ten directions of nature, prostrating before the Buddhas..." (Pañcasutra, 2017). This is a flexible and easy coaching method (Pañcasutra, 2017). Before Buddhism was introduced to China, emphasizing moral rules and rituals was essential to the indigenous Chinese culture (Kalupahana, 1993). Understanding Maitreya Buddhism must understand Chinese Buddhism.

Lewis concludes that Buddhist rituals have been consciously designed and usefully shape the life experiences of their adherents; when excited, these practices ultimately lead them away from suffering and towards progress in spiritual maturity (Lewis, 2015). However, according to Payne, rituals do not have a place in the hearts of the Buddhist intellectual community. One of the western images of Buddhism is that this religion has historically avoided rituals (Payne, 2018).

This perception is a singular interpretation of the Buddhist view of ritual. Perhaps Buddha denied that rituals could purify people just as people would not become holy by performing ritual baths in the Ganges. Buddha did not deny that good rituals could build individual spirituality. Especially for married people, de Bary in Lewis, T. (2015) asserts, "even two of the five obligations of a child in the Sigālovāda Sutta are to continue family traditions and perform ritual offerings to relatives who have died." According to Payne, R. (2018), rejection of Brahmin sacrificial rituals, which involve sacrificing live animals, is not a rejection of rituals.

The review of previous studies includes research with the theme of Mindfulness, Ritual, and Spirituality conducted on (a) religiosity and meditation and ability in psychological adjustment (Montero-Marin et al., 2019); (b) the relationship between mental health, spirituality, and religion (Ahmadi \& Shahmohammadi, 2015); (c) student Spiritual Competence (Novitasari, 2017); (d) relationship of spiritual well-being with mindfulness, compassion, and satisfaction with life (Mathad et al., 2019). Judging from several aspects, this research's novelty and originality (state of the art) is the methodology - the approach, method, theme, and focus of this research study - the basic techniques are the same but are different from other studies. The location of the study is also a strength in this study because there has never been any previous research done at the Maitreyawira Buddhist High School Pekanbaru. In addition, this Buddhist higher education institution is the only higher education based on the Maitreya devotional, which has a distinctive method of fostering and developing spirituality, mindfulness, and Buddhist religious rituals.

This study aims to obtain an overview of the influence of mindfulness and Buddhist rituals on students' spirituality at STAB Maitreyawira Pekanbaru, either individually or jointly.

\section{Method}

This study used a quantitative approach with slovin's formula sampling technique. The variables were mindfulness $\left(\mathrm{X}_{1}\right)$ and Buddhist religious rituals $\left(\mathrm{X}_{2}\right)$ as the independent variable and spirituality (Y) as the dependent variable. The instrument used to measure spirituality was guided by the SAIL (Spiritual Attitude and Involvement List) from Meezenbroek (Meezenbroek, Garssen, Berg, \& Tuytel, 2012). The respondents of this study were 106 samples from 144 students of STAB Maitreyawira Pekanbaru batch 2018, 2019, and 2020. 
The instrument used to measure Mindfulness was adopted from the original long-form version of The Five Facet Mindfulness Questionnaire (FFMQ), published by (Chowdhury, 2020). This test consisted of 39 items measuring five aspects: observing, describing, acting with awareness, non-judgmental, and not reacting. The tool was developed by Ruth Baer, a professor, and mindfulness-based researcher, at the University of Kentucky, and her team (Baer et al., 2014).

The instrument used to measure student Buddhist religious rituals was built on a literature review, consisting of 40 items measuring seven aspects: routine and repetition, sacredness, adjustment and belief, aesthetic behavior, awareness and willingness, formality, and symbolism. Moreover, the data collection in this study used a survey method. The questionnaire used in this study is closed-ended questions.

The answer choices available on a five-point with Likert scale were: (1) not at all, (2) rarely, (3) sometimes, (4) often, and (5) very often. There were two scoring patterns involved in this mindfulness instrument and Buddhist ritual: 1) direct scoring - where items were scored according to a Likert score (for example, 1 will add a score of 1 and 4 will add a value of 4) and 2) reverse scoring - where we rated items in reverse (for example, 1 means a score of 5 , and 5 means a score of 1, 4 means a score of 2 , and so 2 means a score of 4 ). The sum of the items scored directly and inversely gave the total score. The score provided an estimate of the student's position in terms of variables.

The method in this study was a survey method analyzed with the Pearson correlation test and multiple regression analysis with the help of SPSS version 16.0. The classical assumption test used in this study was the normality test, multicollinearity test, and heteroscedasticity test. To test the research hypothesis, a simple correlation test, multiple correlations, determination (R \& R-Square), and the calculation of the effective contribution (EC) and relative contribution (RC) were carried out.

\section{Findings}

This research was conducted at STAB Maitreyawira Pekanbaru which is located at the Bumi Suci Maitreya Education and Training Center complex, Bukit Barisan III Riau Ujung Street, Tampan Village, Payung Sekaki District, Pekanbaru, Riau.

STAB Maitreyawira is under the auspices of Yayasan Cipta Kader Maitri under the guidance of Majelis Pandita Buddha Maitreya Indonesia (Mapanbumi). STAB Maitreyawira was founded in 2008 in Jakarta and has graduated 316 students. With various considerations, in 2018, STAB Maitreyawira was moved to Pekanbaru, with the Decision of the Trustees of Yayasan Cipta Kader Maitri on September 3, 2017 (Maitreyawira, 2018).

The respondents of this study were students of STAB Maitreyawira Pekanbaru class 2018, 2019, and 2020. There were 144 STAB Maitreyawira, consisting of 30 students in 2020, 38 students in 2019, and 76 students in 2019. Sampling data used was as much as 106 by the sampling. Characteristics of respondents are presented in table 1 . The distribution of respondents consists of age, gender, and occupation. 
Dharmaji Chowmas, Adi W Gunawan, Sutikyanto
Smaratungga: Journal of Education and Buddhist Studies, Vol. 1, No. 2, December 2021

Table 1. Distribution of Respondents

\begin{tabular}{lcc}
\hline Characteristics of respondents & Quantity & Percentage \\
\hline Gender & 51 & $48 \%$ \\
Male & 55 & $52 \%$ \\
Female & $\mathbf{1 0 6}$ & $\mathbf{1 0 0 \%}$ \\
\hline Total & & \\
\hline Age & 44 & $41,5 \%$ \\
18 - 25 years old & 39 & $36,8 \%$ \\
Between 25-38 years old & 23 & $21,7 \%$ \\
Between 38-65 years old & $\mathbf{1 0 6}$ & $\mathbf{1 0 0} \%$ \\
\hline Total & & \\
Occupation & 32 & $30,2 \%$ \\
Teacher & 30 & $28,3 \%$ \\
Student & 16 & $15,1 \%$ \\
Entrepreneur & 13 & $12,2 \%$ \\
Private Employee & 14 & $13,2 \%$ \\
Monk & 1 & 1 \\
And others & $\mathbf{1 0 6}$ & $\mathbf{1 0 0} \%$ \\
\hline Total &
\end{tabular}

Source: Google forms primary data, 2021

\section{The influence of mindfulness on student spirituality}

Table 2. Mindfulness Test Summary $\left(\hat{\mathrm{Y}}=\mathrm{a}+\mathrm{b}_{1} \mathrm{X}_{1}\right)$

\begin{tabular}{|l|l|c|c|c|c|c|c|c|c|}
\hline \multirow{2}{*}{ Model } & $\mathbf{B}$ & \multicolumn{3}{c|}{ Beta } & \multicolumn{2}{c|}{$\mathbf{t}$} & \multicolumn{2}{|c|}{ F } & Sig. \\
\cline { 3 - 10 } & & $\mathbf{R}$ & $\mathbf{R}_{\mathbf{n} 106}$ & $\mathbf{R}^{\mathbf{2}}$ & Count & $\mathrm{t}_{(0,025 ;}$ & Count & $\mathrm{F}_{(1 ; 104)}$ & \\
\hline (Constant) & 39.511 & & & & & & & & 0,000 \\
\hline Mindfulness & 0,516 & 0,560 & 0,1904 & 0,313 & 6,890 & 1,983 & 47.476 & 3,932 & 0,000 \\
\hline
\end{tabular}

a. Predictors: (Constant), Mindfulness

b. Dependent Variable: Spirituality

Primary Data processed by SPSS Ver.16, 2021

Table 2 shows that $t_{\text {count }}$ is $6.890>$ table is 1.983 with a significance level (sig.) of 0.000 less than probability $0.05(0.000<0.05)$ and $F_{\text {count }} 47.476>F_{\text {table }} 3.932$. The results of a simple regression test with a correlation coefficient (R) of 0.560 at a significance level of $5 \%$, then $r_{\text {count }}>r_{\text {table }}(0.516>0.1904)$. So, the hypothesis is fulfilled, in which there is an influence of the mindfulness variable on the spirituality variable. The results of the coefficient of determination of the mindfulness variable on the spirituality variable in table 1 . show $31.3 \%(0.313)$. The variance of student spirituality can be explained by mindfulness through the regression equation $\hat{Y}=$ $39.511+0.516 \mathrm{X}_{1}$, while variables influence the remaining $68.7 \%$. Others include Buddhist religious rituals and variables not examined in this study. 
Dharmaji Chowmas, Adi W Gunawan, Sutikyanto
Smaratungga: Journal of Education and Buddhist Studies, Vol. 1, No. 2, December 2021

\section{The Influence of Buddhist rituals on student spirituality}

Table 3. Summary of Regression Test Results for Buddhist religious rituals $\left(\hat{Y}=a+b_{2} X_{2}\right)$

\begin{tabular}{|c|c|c|c|c|c|c|c|c|c|}
\hline \multirow{2}{*}{ Model } & $\mathbf{B}$ & \multicolumn{4}{|c|}{ Beta } & \multicolumn{3}{|c|}{ t } & \multicolumn{2}{|c|}{$\mathbf{F}$} & Sig. \\
\cline { 3 - 10 } & 26,016 & $\mathbf{R}$ & $\mathbf{R}_{\mathbf{n} 106}$ & $\mathbf{R}^{2}$ & Count & $\mathrm{t}_{(0,025 ; 104)}$ & Count & $\mathrm{F}_{(1 ; 104)}$ & \\
\hline (Constant) & & & & & & & & 0,002 \\
\hline $\begin{array}{l}\text { Buddhist } \\
\text { rituals }\end{array}$ & 0,503 & 0,617 & 0,1904 & 0,381 & 8,003 & 1,983 & 64,045 & 3,932 & 0,000 \\
\hline
\end{tabular}

a. Predictors: (Constant), Buddhist religious rituals

b. Dependent Variable: Spirituality

Primary Data processed by SPSS Ver.16, 2021

Table 3 presents a significance value (sig.) of 0.000 which is less than < probability 0.05 , $t_{\text {count }}$ is $8.003>t$ table is 1.983 . The value of the correlation coefficient $(R)$ of 0.617

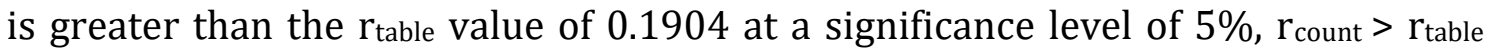
(0.617>0.1904). So, the hypothesis is fulfilled; there is an influence of Buddhist religious rituals on spirituality. The test results of the coefficient of determination of the Buddhist religious ritual variable on the spirituality variable in table 2 show $38.1 \%(0.381)$ of the variance of student spirituality can be explained by Buddhist religious rituals through the regression equation $\hat{Y}=26.016+0.503 \mathrm{X}_{2}$.

\section{The influence of mindfulness and Buddhist rituals on spirituality}

Table 4. Summary of Multiple Regression Significance Test Results between Mindfulness $\left(\mathrm{X}_{1}\right)$ dan Buddhist Religious Rituals $\left(\mathrm{X}_{2}\right)$ and Spirituality $(\mathrm{Y})$

\begin{tabular}{|c|c|c|c|c|c|c|c|c|}
\hline \multirow[b]{2}{*}{ Model } & \multirow[b]{2}{*}{ B } & \multirow[b]{2}{*}{$\mathbf{R}$} & \multirow[b]{2}{*}{$\mathbf{R}^{2}$} & \multicolumn{2}{|c|}{ Contribution } & \multicolumn{2}{|c|}{$\mathbf{F}$} & \multirow[t]{2}{*}{ Sig. } \\
\hline & & & & $\begin{array}{l}\text { Effective } \\
\text { (EC) }\end{array}$ & $\begin{array}{l}\text { Relative } \\
\text { (RC) }\end{array}$ & Count & $F_{(1 ; 103)}$ & \\
\hline (Constant) & 8,681 & & & & & & & 0,293 \\
\hline Minfulness & 0,338 & $0.702^{\mathrm{a}}$ & 0,492 & $20,49 \%$ & $41,66 \%$ & 49.913 & 3,933 & 0,000 \\
\hline $\begin{array}{l}\text { Buddhist } \\
\text { rituals }\end{array}$ & 0,379 & & & $28,69 \%$ & $58,34 \%$ & & & 0,000 \\
\hline
\end{tabular}

a. Predictors: (Constant), Buddhist religious rituals and mindfulness

b. Dependent Variable: Spirituality

Primary Data processed by SPSS Ver.16, 2021

Table 3 data provides information that the significance value of the variable mindfulness and Buddhist religious rituals is 0.000 , which means less than the probability of 0.05 and $F_{\text {count }}=49,913$, which is greater than $\mathrm{Ft}_{\text {able }}$ (3.933). This means that the mindfulness and Buddhist religious ritual variables affect the spirituality variable, accepting the hypothesis. Rsquare obtained 0.492 or equal to $49.2 \%$. That is, $49.2 \%$ of students' spirituality valence can be explained by the mindfulness variable $\left(\mathrm{X}_{1}\right)$ and the Buddhist religious ritual variable $\left(\mathrm{X}_{2}\right)$ together through the regression equation $\hat{Y}=8.681+0.338 \mathrm{x}_{1}+0.379 \mathrm{x}_{2}$. The rest $(100 \%-$ $49.2 \%=50.8 \%$ ) is influenced by other variables not examined.

Table 3 data also illustrates that the effective contribution of the mindfulness variable $\left(\mathrm{X}_{1}\right)$ to the spirituality variable $(\mathrm{Y})$ is $20.49 \%$. Meanwhile, the effective contribution of the Buddhist religious ritual variable $\left(\mathrm{X}_{2}\right)$ to the spirituality variable 
$(\mathrm{Y})$ is $28.69 \%$. The calculation of the relative contribution shows that there is $41.66 \%$ of the relative contribution of the mindfulness variable $\left(\mathrm{X}_{1}\right)$ to spirituality (Y) and $58.34 \%$ of the relative contribution of the Buddhist religious ritual variable $\left(\mathrm{X}_{2}\right)$ to spirituality (Y). Thus, it can be concluded that the Buddhist religious ritual variable $\left(\mathrm{X}_{2}\right)$ has a more dominant influence $(58.34 \%)$ on the spirituality variable (Y) than the mindfulness variable $\left(\mathrm{X}_{1}\right)$, which is only $41.66 \%$.

\section{Discussion}

This study aims to obtain an overview of the influence of mindfulness and Buddhist religious rituals on the spirituality of STAB Maitreyawira Pekanbaru students. Based on the research data analyzed, a summary of the research results can be seen in Figure 4.3. Research Summary.

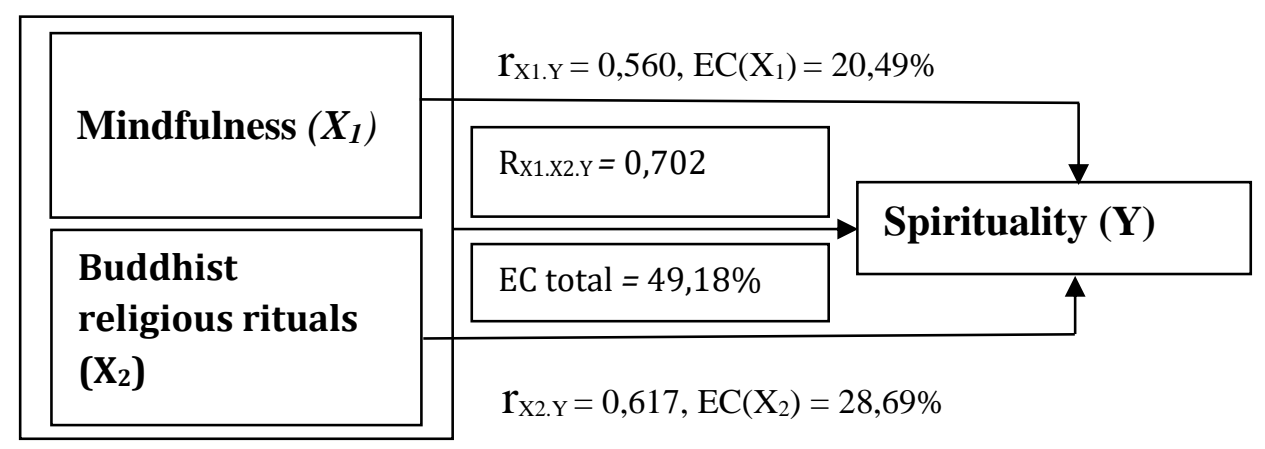

Figure 1. Research Summary (source: Primary Data processed by SPSS Ver.16, 2021

\section{The Influence of mindfulness $\left(X_{1}\right)$ on spirituality $(Y)$}

The results of the simple regression test show that mindfulness has a positive and significant effect on the spirituality of students at STAB Maitreyawira Pekanbaru. The correlation coefficient (rx1y) of 0.560 is greater than the rtable value of 0.1909 , so $r_{\text {count }}>$ rtable $(0.516>0.1909)$, so that the value is significant. In addition, because this value is positive, it can be stated that the mindfulness variable positively affects the spirituality of students at STAB Maitreyawira Pekanbaru. This illustrates that the higher students' mindfulness at STAB Maitreyawira Pekanbaru, the higher the spirituality of students at STAB Maitreyawira Pekanbaru. On the other hand, the lower the mindfulness of students at STAB Maitreyawira Pekanbaru, the lower the spirituality of students at STAB Maitreyawira Pekanbaru. In other words, students' spirituality at STAB Maitreyawira Pekanbaru can be improved by increasing mindfulness.

These results are by the research of Mathad et al. (2019), Dami et al. (2018), and Liu et al. (2020), stating that increasing mindfulness increases spirituality. Fouriana listyawati's research (2017) also explains a relationship between spiritual well-being and mindfulness. Research (Tirto \& Kahija, 2015) also says that mindfulness increases religious understanding, increasing spirituality.

The results of this study are also in line with Burmansah et al. (2019) that in some ways, the practice of mindfulness makes practitioners have a more calm and peaceful level of thought and can respond with compassion and understanding. The 
ability to respond with compassion and understanding signifies increased spirituality. This is in line with Tirto \& Kahija's (2015) research on the meaning of monks towards mindfulness practices, finding that subjects have personal meanings related to mindfulness in their lives. The human tendency to seek meaning is a sign of spirituality (Pasiak, H., 2009).

\section{The influence of Buddhist rituals ( $\left.\mathrm{X}_{2}\right)$ on spirituality (Y)}

The results of the simple regression test show that Buddhist rituals have a positive and significant influence on the spirituality of STAB Maitreyawira Pekanbaru students. The correlation coefficient (rx2y) of 0.617 is greater than the

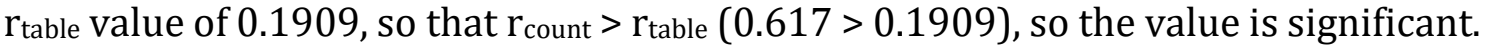
In addition, because this value is positive, it can be stated that the variable of Buddhist religious rituals positively affects students' spirituality at STAB Maitreyawira Pekanbaru.

These results show that the higher the Buddhist religious rituals students at STAB Maitreyawira Pekanbaru, the higher the spirituality students possess at STAB Maitreyawira Pekanbaru. Conversely, the lower the Buddhist religious rituals owned by STAB Maitreyawira Pekanbaru students, the lower the spirituality possessed by STAB Maitreyawira Pekanbaru students. In other words, the spirituality of STAB Maitreyawira Pekanbaru students can be improved through increasing Buddhist religious rituals for STAB Maitreyawira Pekanbaru students.

This result agrees with Lewis, T. (2015), which states that the implementation of rituals can be an accumulation of spiritual progress. Srivastava and Barmola (2013) argue that rituals are directly or indirectly beneficial for spirituality. Spiritual support is needed when someone is experiencing stress. One of the efforts that can be done to prevent and reduce the burden of problems is through religious rituals (Susanto \& Dewi, 2019). Forms of spiritual practice include prayer rituals, liturgical dances, singing, and practices that involve all human senses (NelsonBecker \& Sangster, 2019). Research conducted by Mappiasse \& Uwen (2020) explains that the quality of religious rituals is related to the maturity of religious spirituality. Nelson-Becker and Sangster (2019) also argue that ritual plays a role in fulfilling spirituality.

\section{The Influence of mindfulness $\left(X_{1}\right)$ and Buddhist rituals $\left(X_{2}\right)$ on student spirituality (Y)}

The calculation results show that the effective contribution of the mindfulness variable $\left(\mathrm{X}_{1}\right)$ to the spirituality variable $(\mathrm{Y})$ is $20.49 \%$. Meanwhile, the effective contribution of the Buddhist religious ritual variable $\left(\mathrm{X}_{2}\right)$ to the spirituality variable $(\mathrm{Y})$ is $28.69 \%$. The calculation of the relative contribution shows that there is $41.66 \%$ of the relative contribution of the mindfulness variable $\left(\mathrm{X}_{1}\right)$ to spirituality $(\mathrm{Y})$ and $58.34 \%$ of the relative contribution of the Buddhist religious ritual variable $\left(\mathrm{X}_{2}\right)$ to spirituality $(\mathrm{Y})$. Thus, the Buddhist religious ritual variable $\left(\mathrm{X}_{2}\right)$ has a more dominant influence $(58.34 \%)$ on the spirituality variable $(\mathrm{Y})$ than the mindfulness variable $\left(\mathrm{X}_{1}\right)$, which is only $41.66 \%$.

Based on these calculations, it can be concluded that the hypothesis is fulfilled; there is a positive and significant effect on the mindfulness variable and the 
Buddhist religious ritual variable together on the spirituality variable for students at STAB Maitreyawira Pekanbaru.

These results are supported by the research of Sollgruber et al., which says there is a direct relationship between mindfulness and religious spirituality, and there is an indirect relationship between ritual and spirituality (Sollgruber et al., 2018). Meditation traditionally includes rituals. Rituals and meditation directly or indirectly affect one's spirituality. This view is per the opinion of Doyle, S. (2020). According to Payne, R. (2018), meditation is a mental activity, and ritual is physical. Among mindfulness, religious rituals and spirituality are interconnected. Rituals can increase one's mindfulness and spirituality. These results come from the research by Albatnuni, M. (2020), showing that frequent and continuous prayer promotes higher mindfulness and life satisfaction. This effect may be explained by the influence of spirituality and a sense of optimism.

\section{Conclusion}

The results of this study show that there is a positive and significant influence between mindfulness on the spirituality of students at STAB Maitreyawira Pekanbaru. Thus, students' spirituality at STAB Maitreyawira Pekanbaru can be improved through increased mindfulness and Buddhist rituals. This research shows that to cope with academic stress, students can improve their spirituality by giving meaning to their lives through mindfulness and an active role in Buddhist religious rituals. However, more comprehensive research is needed with more in-depth methods, broader variables, and more flexible data collection techniques, such as the mixed-method approach, to obtain complete information about the factors influencing student spirituality.

\section{Acknowledgment}

We would like to thank those who have provided support, motivation, and assistance in this research, especially the college colleagues and Zhuo's family. Moreover, thank the Head of the Department of Buddhist Religious Education STAB Maitreyawira, Dr. Yadi Sutikno, M.Pd., who has granted research permission at STAB Maitreyawira Pekanbaru.

\section{References}

Alimuddin, T. (2018). Pengaruh Spiritual Mindfulness Based on Breathing Exercise Terhadap Kecemasan, Kadar Glukosa Darah dan Tekanan Darah Pasien Diabetes Melitus Tipe 2. Repository.Unair.Ac.Id.

Anggutara Nikāya. (2015). Añguttara Nikāya (B. Bodhi (ed.)). http://dhammacitta.org

Ahmadi, A., \& Shahmohammadi, N. (2015). Studying the Relationship between Mental Health, Spirituality, and Religion in Female Students of Tehran Azad University: South Branch. Procedia - Social and Behavioral Sciences, 205(May), 236-241. doi: 10.1016/j.sbspro.2015.09.065

Albatnuni, M. (2020). Prayer and Well-being: Do Mindfulness, Optimism, Spirituality, and Social Support Mediate a Relationship between Prayer and Well-being in a 
Canadian-Muslim Population? [University of Ottawa]. In Malaysian Palm Oil Council (MPOC) (Vol. 21, Issue 1). http://mpoc.org.my/malaysian-palm-oilindustry/

Albrecht, N. J., Albrecht, P. M., Cohen, M., Albrecht, N. J., Albrecht, P. M., \& Cohen, M. (2012). Mindfully teaching in the classroom: a literature review. Australian Journal of Teacher Education, 37(12). doi: 10.14221/ajte.2012v37n12.2

Ananda, D., Kurniawan, A., Santosa, H. (2014). Pūjā. Yogyakarta: Insigh Vidyasena Production

Azman, A., \& Syamsuddin. (2012). Memahami dimensi spiritualitas dalam praktek pekerjaan sosial. Informasi, 17(02), 111-119.

Baer, R., Baer, R. A., Smith, G. T., Hopkins, J., Krietemeyer, J., \& Toney, L. (2014). Using Self-Report Assessment Methods to Explore Facets of Mindfulness. April 2006. doi: 10.1177/1073191105283504

Burmansah, B., Mukhtar, M., Ruqaiyah, R., Nabilah, S., Ripki, A. J. H., \& Fatayan, A. (2019). Mindful leadership: the ability of the leader to develop compassion and attention without judgment - a case study of the leader of Buddhist higher education institute. European Journal of Educational Research, 9(1), 51-65. doi: 10.12973/eu-jer.9.1.51

Cernetic, M. (2018). Mindfulness in Christian spiritual practices and connections with psychotherapy. Kairos, 12(3-4), 99-123.

Chowdhury, M. R. (2020). The Five Facet Mindfulness Questionnaire (FFMQ). https://optimistminds.com/five-facet-mindfulness-questionnaire/ (accessed in December 2020)

Dami, Z. A., Tameon, S. M., \& Alexander, F. (2018). Spiritual well-being as variable intervening mindfulness dan life satisfaction. Konselor, 7(4), 124-137. doi: 10.24036/0201874102383-0-00

David J. Kalupahana. (1993). Buddhist thought and ritual. In Teaching Philosophy, 16(3). doi: 10.5840/teachphil19931631

Dīgha Nikāya (Collection of Long Discourses) Vol. III. (2009). Jakarta: Dhammacitta Press.

Doyle, S. (2020). A Meditation Ritual that Will Transform Your Life. Australian School of Meditation \& Yoga. https://asmy.org.au/meditation/a-meditation-ritualthat-will-transform-your-life/

Fouriana, listyawati, E. (2017). Kesejahteraan spiritual dan mindfulness pada Majelis Sahabat Shalawat. Jurnal Psikologi Islami, 2(3), 79-85.

Gutierrez, A. S., Krachman, S. B., Scherer, E., West, M. R., \& Gabrieli, J. D. E. (2019). Mindfulness in the Classroom: Learning from a School-based Mindfulness Intervention through the Boston Charter Research Collaborative Transforming Education. January. Harvard University.

Hakisukta. H. (2018). Efektifitas Mindfulness Training Untuk Meningkatkan Kebahagiaan Pada Remaja Dengan Pola Asuh Otoriter. Medan: Universitas Sumatera Utara.

Hidayat, S. (2019). Spirituality and Holiness in Buddhism Konkritisasi Jalan Menuju Pembebasan. (H. Bramantyo (ed.); Pertama). Bogor: Pustaka Amma Alamia.

Kabat-Zinn, J. (2015). Mindfulness for Beginners - Reclaiming the Present Moment and Your Life. Sounds True, Inc. https://doi.org/eBook ISBN: 978-1-60407753-7 
Kharlas, D. (2018). The Development and Validation of a Preliminary Meditation. Scholarship @Western.Western University

Lewis, T. (2015). A History of Buddhist Ritual. In The Buddhist World (pp. 318-337). https://www.academia.edu/18473908/A_History_of_Buddhist_Ritua/Book Section (Akses 25 Agustus 2020)

Liu, C., Chen, H., Liu, C.-Y., Lin, R.-T., \& Chiou, W.-K. (2020). The Effect of LovingKindness Meditation on Flight Attendants' Spirituality, Mindfulness and Subjective Well-Being. Healthcare, 8, 174. doi: 10.3390/healthcare8020174

Mappiasse, S., \& Uwen, N. I. (2020). Ritual dan spiritualitas keagamaan mahasiswa muslim di wilayah minoritas plural. Jurnal Ilmiah Iqra', 14(2), 96. doi: 10.30984/jii.v14i2.1371

Maitreyawira (2018). Profil STAB Maitreyawira. https://maitreyawira.ac.id/pages/tentang-kami/profil-stab-maitreyawira (accessed on February 16 2021)

Majjhima Nikāya (Collection of Middle-length Discourses) Vol. I. (2009). Jakarta: Dhammacitta Press.

Mathad, M. D., Rajesh, S. K., \& Pradhan, B. (2019). Spiritual well-being and its relationship with mindfulness, self-compassion and satisfaction with life in baccalaureate nursing students: a correlation study. Journal of Religion and Health, 58(2), 554-565. doi: 10.1007/s10943-017-0532-8

Meezenbroek, E. de J., Garssen, B., Berg, M. van den, Dierendonck, D. van, Visser, A., Schaufeli, W. B., \& Published. (2012). Measuring spirituality as a universal human experience: a review of spirituality questionnaires. Journal of Religion and Health, 51(2), 336-354. doi: 10.1007/s10943-010-9376-1

Meezenbroek, E. de J., Garssen, B., Berg, M. VAN, \& Tuytel, G. (2012). Measuring spirituality as a universal human experience: development of the Spiritual Attitude and Involvement List (SAIL). Journal of Psychosocial Oncology, 30(2), 141-167. doi: 10.1080/07347332.2011.651258

Montero-Marin, J., Perez-Yus, M. C., Cebolla, A., Soler, J., Demarzo, M., \& GarciaCampayo, J. (2019). Religiosity And Meditation Practice: Exploring Their Explanatory Power On Psychological Adjustment. Frontiers in Psychology, 10(MAR). doi: 10.3389/fpsyg.2019.00630

Muslimin, M. (2013). Mengenal dasar spiritualitas umat Buddha. Jurnal Studi Lintas Agama, 8(1), 71-88.

Nelson-Becker, H., \& Sangster, K. (2019). Recapturing the power of ritual to enhance community in aging. Journal of Religion, Spirituality and Aging, 31(2), 153-167. doi: 10.1080/15528030.2018.1532858

Niekerk, B. Van. (2018). Religion and spirituality: What are the fundamental differences? HTS Teologiese Studies/Theological Studies, 74(3), 1-11. doi: 10.4102/hts.v74i3.4933

Novitasari, Y. (2017). Kompetensi spiritualitas mahasiswa. JOMSIGN: Journal of Multicultural Studies in Guidance and Counseling, 1(1), 45. doi: 10.17509/jomsign.v1i1.6051

Pancasutra. (2017). Sutra Pertanyaan Bodhisatva Maitreya tentang Ikrar Dasar Kebuddhaan. In "Pancasutra Maitreya". Deli Serdang: DPP Mapanbumi. Sutra ke 4, hal. 115 .

Pascoe, M. C., Hetrick, S. E., \& Parker, A. G. (2020). The impact of stress on students 
in secondary school and higher education. International Journal of Adolescence and Youth, 25(1), 104-112. doi: 10.1080/02673843.2019.1596823

Pasiak, H. T. F. (2009). Model penjelasan spiritualitas dalam konteks neurosains. UIN Sunan Kalijaga Yogyakarta.

Payne, R. K. (2018). Intertwined Sources of Buddhist Modernist Opposition to Ritual : History, Philosophy, Culture. 94-95. doi: 10.3390/rel9110366

Samyutta Nikāyes (Connected Dissources or Kindred Sayings) Vol. V. (2009) Jakarta: Dhammacitta Press.

Sollgruber, A., Bornemann-Cimenti, H., Szilagyi, I. S., \& Sandner-Kiesling, A. (2018). Spirituality in pain medicine: A randomized experiment of pain perception, heart rate and religious spiritual well-being by using a single session meditation methodology. Plos One, 13(9), 1-18. doi: 10.1371/journal.pone.0203336

Srivastava, S., \& Barmola, K. C. (2013). Rituals in Hinduism as related to spirituality. Indian Journal of Positive Psychology, 4(1), 87-95. doi: 10.15614/ijpp/2013/v4i1/49823

Susanto, J., \& Dewi, T. T. (2019). Aktivitas Kebutuhan Spiritual Dengan Depresi Pada Lansia. Fakultas Keperawatan Vokasi Universitas Airlangga, JOHC Website: http:/johc.umla.ac.id/index.html, 1-16.

Tirto, A. R., \& Kahija, Y. F. La. (2015). Pengalaman biksu dalam mempraktikkan mindfulness (sati/ kesadaran penuh). Empati, 4(2), 126-134.

Yusuf, A., Nihayati, H. E., Iswari, M. F., \& Okviasanti, F. (2017). Kebutuhan Spiritual; Konsep dan Aplikasi dalam Asuhan Keperawatan (Issue December 2016). Mitra wacana media. 